\title{
Public Complaint Application (Case Study of RSUDYA Tapaktuan Based On Android)
}

\author{
Fardiansyah $^{\mathrm{a}, 1,{ }^{*}}$, Sera Delta Tanjung ${ }^{\mathrm{b}, \mathrm{c}, 2}$, Sri Mulia Rezeki ${ }^{\mathrm{b}, 3}$ \\ a,b,c Politeknik Aceh Selatan, Jl. Merdeka Komplek Reklamasi Pantai Tapaktuan, Indonesia \\ ${ }^{1}$ fardian.poltas@gmail.com*; ${ }^{*}$ sera.aneukmatematika92@gmail.com; ${ }^{3}$ muliasrirezeki.poltas16@gmail.com \\ *fardian.poltas@gmail.com
}

Article history:

Accepted

Keywords:

RSUDYA Tapaktuan;

Public Complaint;

Android;

Information System;
Yuliddin Away Regional General Hospital (RSUDYA) as an institution provides individual health services in a complete manner that often experiences obstacles in providing optimum services to community, in some cases, complaints from the public. During this time, complaints are accommodated by the existence of a complaint box in each service division, but the use of this method is difficult to obtain accurate information and the process of executing these complaints requires a relatively long period. The implementation of information and communication technology in the form of applications is expected to improve responsive and informative service quality. Through the Android-based Complaints application, it was found that with the use of this application the community was easy in providing advice and criticism of the services of Yuliddin Away Hospital.

\section{Introduction}

In current technological developments, the system is prone to use computer-based systems and telecommunications networks (such as the internet or others). So the authors apply the android studio for making hospital complaints applications because it has various advantages. One of the virtues of Android is that its licenses are open source and free so they are free to develop because there are no royalty fees or distributed in any form. This makes it easy for programmers to create new applications in it. In addition, android is also a media that can explore the capabilities of GIS through Google Maps [1].

Each hospital, of course, tries to provide the best service to patients or the community, as health workers there must be negligence in providing services to patients, such as patients who are late handled by doctors, or rooms that are less comfortable to be occupied by patients. Based on interviews that have been done on people who are hospital patients Tapaktuan, that complaints and grievances are not conveyed accurately and require a relatively long time. In addition to the complaints and grievance system that was submitted directly to the hospital, the suggestion box media was also used before, but it did not work effectively because of the lack of community participation.

Quality of service as a result of a system within the health care organization is affected by the component structures and processes. Organization (structure and culture), management, human resources, technology, equipment, finance are components of the structure. Service processes, action procedures, information systems, administrative systems, control systems, guidelines are process components. The quality of hospital services can be seen in terms of aspects as follows: clinical aspects (doctor, nurse and medical-related services), aspects of service efficiency and effectiveness, patient safety and patient satisfaction. 


\section{Related Work}

In a study conducted by [2], a study was conducted at Dr. Soedomo Trenggalek Regional Hospital with the aim of finding out patient complaints through a qualitative approach using interview, observation and documentation data collection techniques. The researcher mentioned the supporting and inhibiting factors in the implementation of the complaint submission service clearly but the requirements factor had not been optimized. Researchers also propose solutions to maximize complaint services through electronic media and social media.

Then in research [3], researchers conducted a descriptive study with a qualitative method approach (interactive model) with the aim to improve the quality of service in order to achieve patient satisfaction. Researchers also proposed a special call center service for complaint services, so that the public could easily give their critics and suggestions to Malang Hospital.

Then in research [4], researchers conducted a qualitative descriptive study of the governance of the delivery of patient complaints about the quality of health services in A. M. Tenggarong Parekesit Hospital. The data analysis model used is the problem analysis / flowchart analysis model.

\section{Method}

\section{A. Implementation Scheme}

In this study, the steps of the research scheme describes in Fig 1.

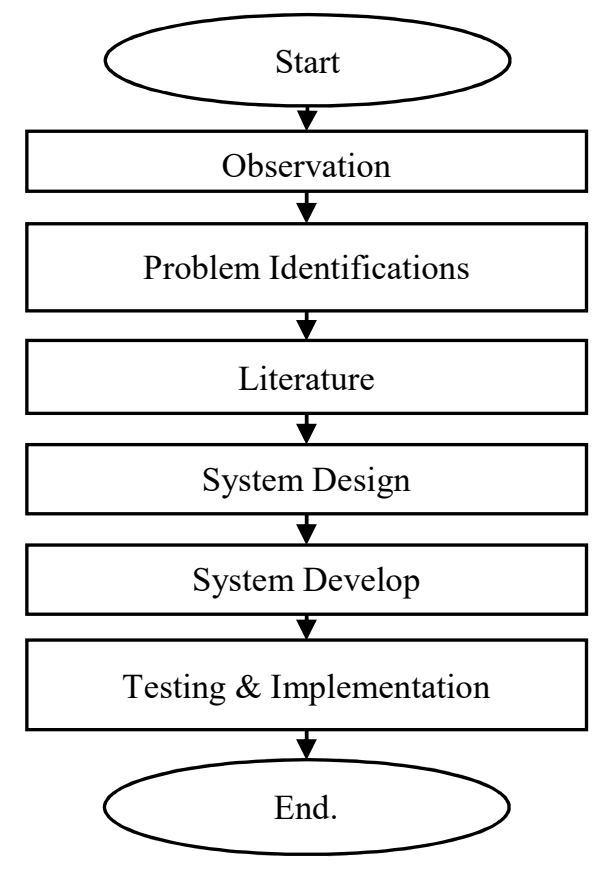

Figure 1. Research Scheme

\section{B. Tool used}

As for supporting the process of implementing this final project, its need several supporting tools which include the following:

1. Hardware

The tools needed in this study are computers or laptops with sufficient specifications to run the working software used.

2. Software

Software used in this study which include the following :

a. Android Studio (tersedia pada https://developer.android.com)

b. JSON (tersedia pada https://www.json.org) 
c. Xampp (tersedia pada https://www.apachefriends.org)

d. Sublimetext (https://www.sublimetext.com)

\section{Implementation Procedure}

The procedure of this research project is carried out by following :

1. Observation

Observation was carried out in order to gather information to explore problems from developing issues.

\section{Identification of Problems}

This activity is carried out after observing and then identifying the problem in order to determine the main points of the problem.

\section{Literature}

In this activity, data and information collection that is relevant to the topic raised is in the form of literature and scientific work.

\section{System Design}

In this activity the application design will be built, the design is in the form of interface design and database design.

\section{System Develop}

This activity involves coding the system that was done before during the design stage.

6. Testing And Implementation

This activity involves the process of testing and implementing applications that have been made.

\section{System Design}

Interface is a communication mechanism between users and the system thats can receive information from users and provide information to users to help direct the search flow of problems until a solution is found. In the description of the application made, it can be shown as the process flow of the application with the flowchart image below.

1. Design Administrator and User Flowchart

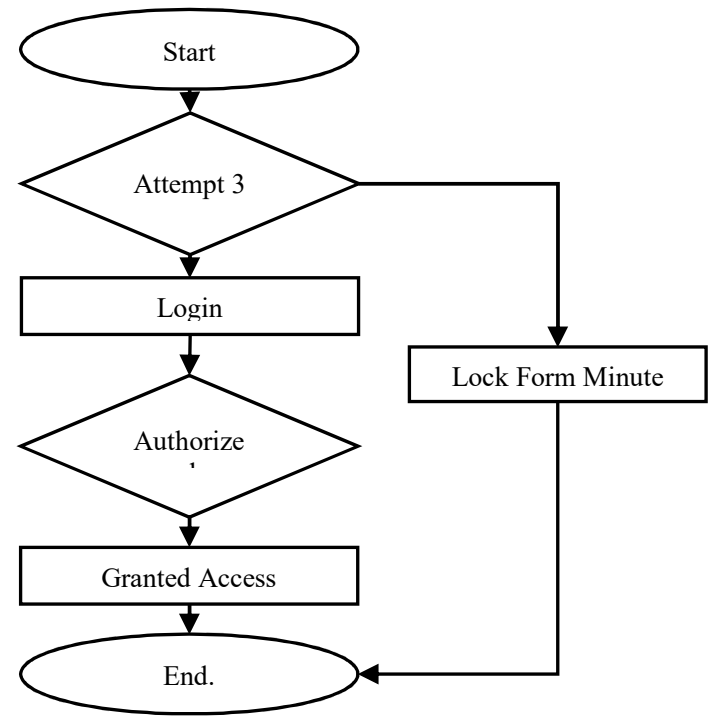

Figure 2. Administrator \& User Flowchart 
2. Design Use case Diagram

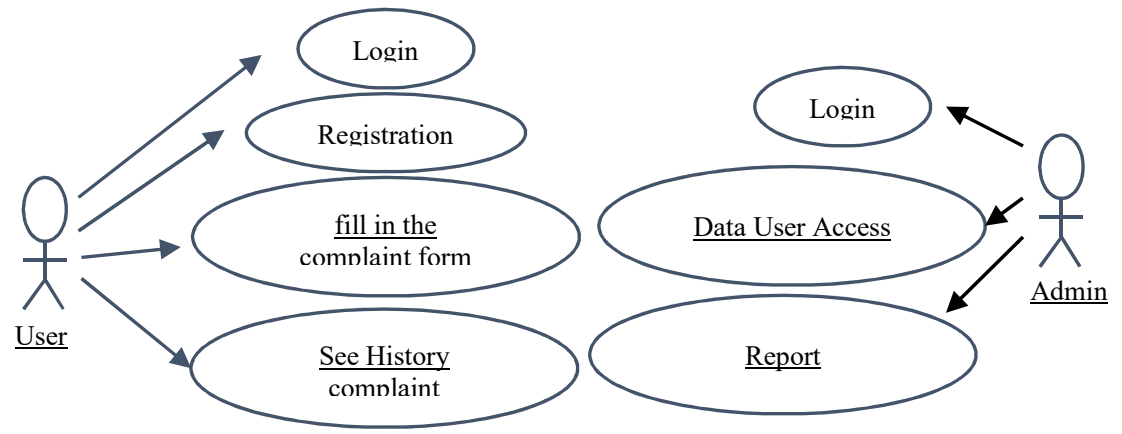

Figure 3. Admin \& User Use case

\section{Result and Discussion}

A. Implementation System

\section{Sistem Pengaduan Online} RSUDYA

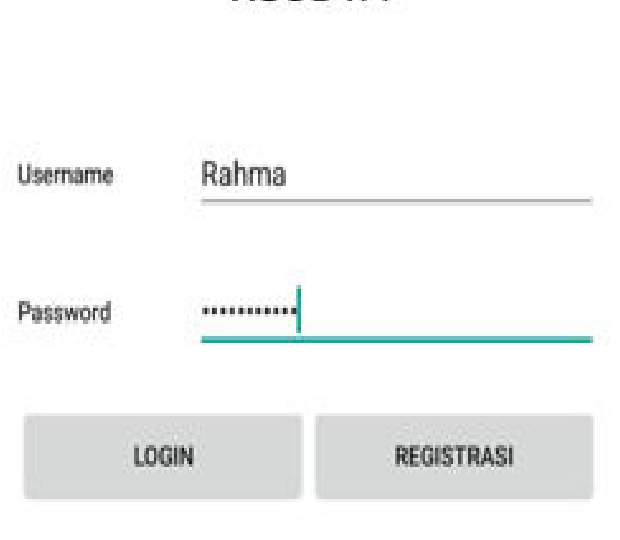

Figure 4. Login Form

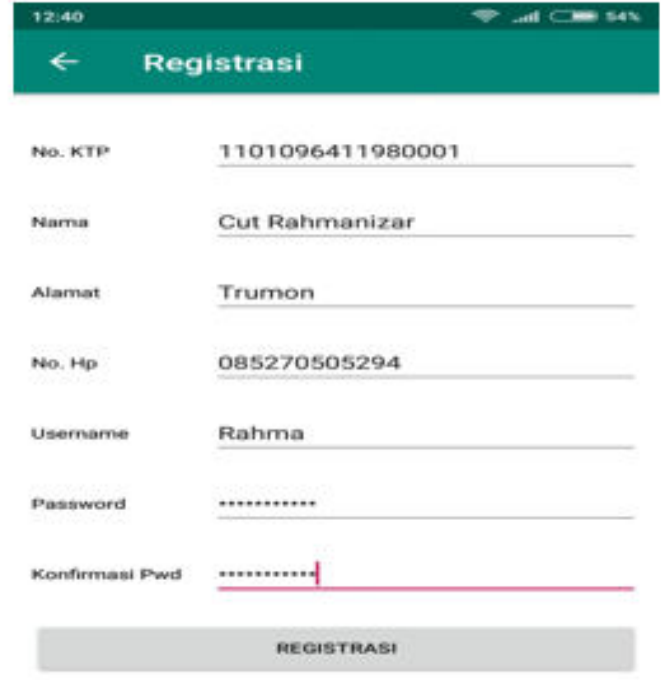

Figure 5. Registration Form

In figure 4 and 5 there is a login menu which is used as a system security from misuse of access rights, so that data security can be guaranteed. Users can only log in to the application if they have previously registered at the registration menu.

In Figures 6, 7 and 8 below, there is a menu display that includes the profiles of RSUDYA Tapaktuan, the workflow in the submission of complaints, complaint services and the history of complaints. In the profile menu describes the vision, mission and history information of RSUDYA Tapak Tuan, this information can be accessed by all users who have been registered into the system. 


$13: 00$

\section{Profil RSUD}

Alur Kerja

\section{Layanan Pengaduan \\ Riwayat Pengaduan}

Logout

Figure 6. Aplications Menu

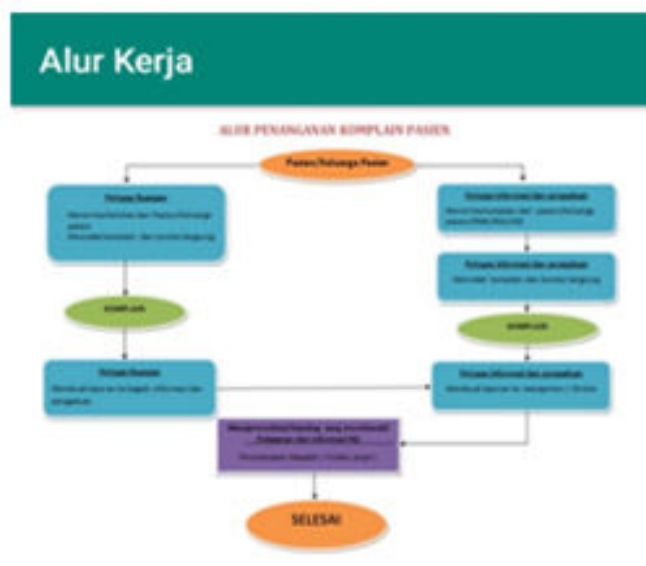

Figure 7. Complaints Workflow

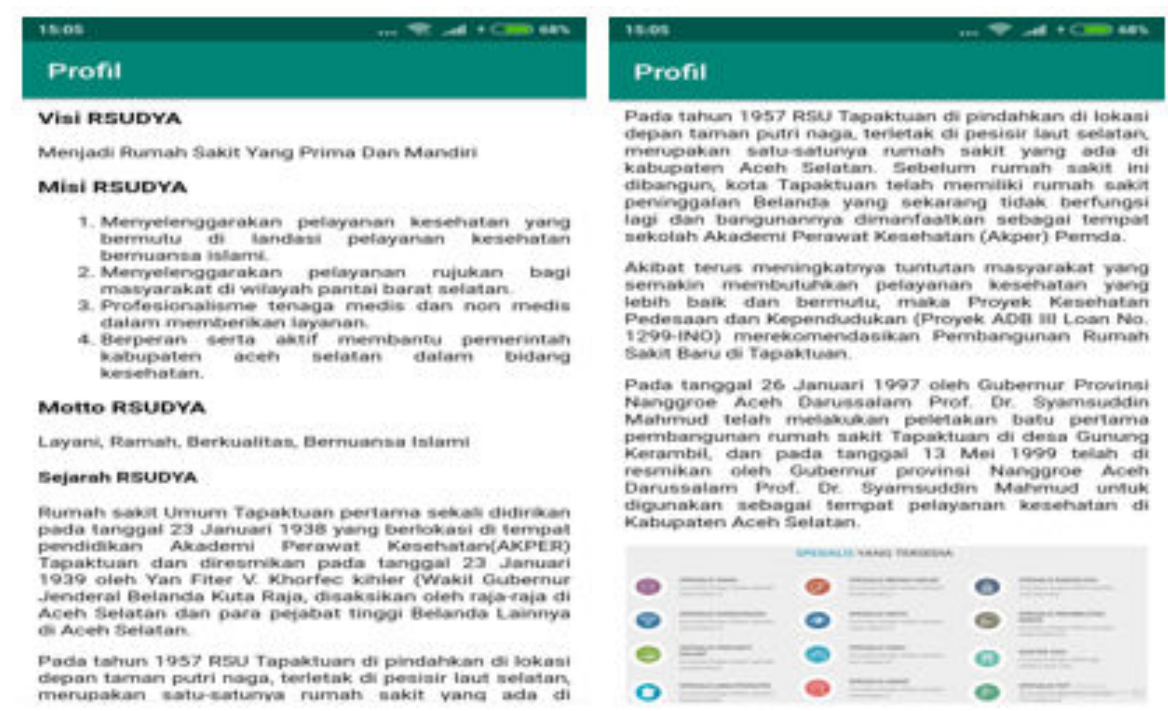

Figure 8. Profile Form

In Figures 9 and 10 explain the complaint service performed by the user. In this section the user can only fill in the complaint form along with the complaint unit. In the complaint history section, the user can see again the contents of the complaint that has been sent and received by the intended unit.

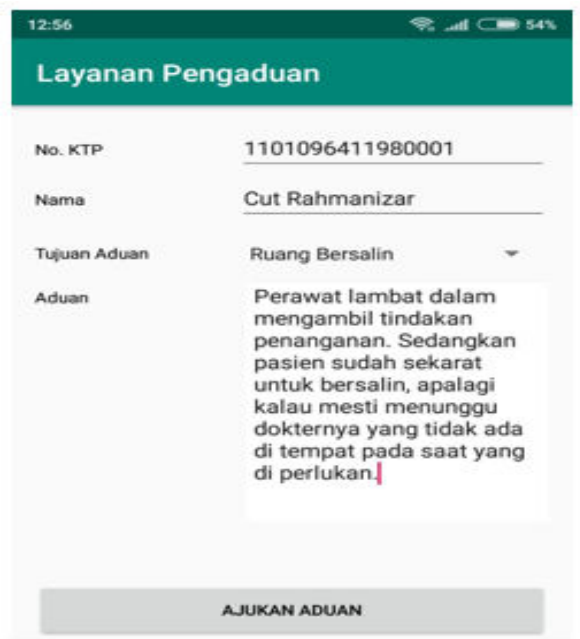

Figure 9. Submit Complaints

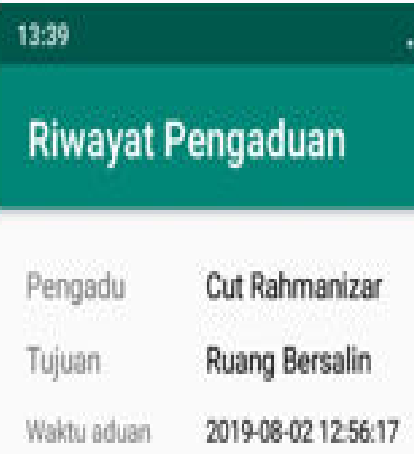

Figure 10. Detail User History 


\section{B. Discussion}

In this study, the process of designing and testing applications for public complaints against the RSUDYA service using the blackbox testing method has been going well and correctly in accordance with the system design process.

\section{Conclusion}

From the results of this study the following conclusions are obtained :

1. Management of public complaints has been able to improve service quality RSUDYA Tapaktuan.

2. The application is user friendly for the average user already has a smartphone based on Android operating system.

\section{References}

[1] Hati, Gusnita Mustika. 2013. Aplikasi Penanda Lokasi Peta Digital Berbasis Mobile GIS Pada Smartphone Android. Volume 2. Nomor 4. ISSN: 2337-845X. Semarang.

[2] N.H. Bella,'Implementasi Unit Pengaduan Masyarakat Dalam Mengetahui Keluhan Pasien”, Jurnal Respon Publik, Vol. 14, No.1, Hal 42-49. ISSN: 2302-8432. Tahun 2020.

[3] A.A. Mazaya et all, "Upaya Peningkatan Pelayanan Kesehatan Rumah Sakit Pada Pasien Rawat Inap Peserta BPJS Kesehatan (Studi Kasus Pada Rumah Sakit Umum Daerah Kota Malang)”, Jurnal Respon Publik, Vol 14. No.1, Hal 19-24. ISSN: 2302-8432. Tahun 2020.

[4] L. Marliana, "Analisis Manajemen Layanan Keluhan Pasien Terhadap Kualitas Layanan Kesehatan Di RSUD AM. Parikesit Tenggarong,” J. Adm. Reform, Vol. 5, No. 2, pp. 69-78, 2017. 